Research Article

\title{
Fluxless Direct Soldering of Transparent Conductive Oxides (TCOs) to Copper
}

\author{
Lung-Chuan Tsao $\mathbb{D}^{1},{ }^{1}$ Cheng-Kai Li $\mathbb{D},{ }^{2}$ Yu-Kai Sun $\mathbb{D}^{\mathrm{D}},{ }^{3}$ Shih-Ying Chang $\mathbb{D}^{2},{ }^{2}$ \\ and Tung-Han Chuang $\mathbb{D}^{3}$ \\ ${ }^{1}$ Department of Materials Engineering, National Pingtung University of Science \& Technology, 91201 Neipu, Pingtung, Taiwan
${ }^{2}$ Department of Mechanical Engineering, National Yunlin University of Science \& Technology, 64002 Douliu, Yunlin, Taiwan
${ }^{3}$ Department of Materials Science and Engineering, National Taiwan University, 10617 Taipei, Taiwan
}

Correspondence should be addressed to Shih-Ying Chang; changsy@yuntech.edu.tw

Received 19 April 2021; Revised 2 August 2021; Accepted 19 October 2021; Published 15 November 2021

Academic Editor: F.H. Samuel

Copyright (c) 2021 Lung-Chuan Tsao et al. This is an open access article distributed under the Creative Commons Attribution License, which permits unrestricted use, distribution, and reproduction in any medium, provided the original work is properly cited.

\begin{abstract}
Due to the combined advantages of low cost, good soldering properties, and appropriate melting temperature range, novel $\mathrm{Sn}_{8} \mathrm{Zn}_{3} \mathrm{Bi}_{1} \mathrm{Mg}$ active solder was developed for direct soldering of transparent conductive oxide (TCO) ceramic targets with oxygen-free copper at $200^{\circ} \mathrm{C}$ in air. The TCO specimens have aluminum-doped zinc oxide (AZO) and zinc oxide (ZnO) ceramics. The direct soldering process was performed without the need for flux or pre-metallization of the two transparent conductive oxides. The microstructure, phase constitution, melting characteristics, and soldering properties of the $\mathrm{Sn}_{8} \mathrm{Zn}_{3} \mathrm{Bi}_{1} \mathrm{Mg}$ active solder were investigated. The liquidus temperature of the $\mathrm{Sn}_{8} \mathrm{Zn}_{3} \mathrm{Bi}_{1} \mathrm{Mg}$ active solder was $198.6^{\circ} \mathrm{C}$, which was very close to the binary $\mathrm{Sn}$ $\mathrm{Zn}$ eutectic temperature of $198.5^{\circ} \mathrm{C}$. The effect of temperature on the bonding strength of the solder joints was evaluated. The shear strengths of $\mathrm{AZO} / \mathrm{Cu}$ and $\mathrm{ZnO} / \mathrm{Cu}$ joints soldered with $\mathrm{Sn}_{8} \mathrm{Zn}_{3} \mathrm{Bi}_{1} \mathrm{Mg}$ active solder were 10.3 and $7.5 \mathrm{MPa}$ at room temperature, respectively. Increasing the temperature from room temperature to $180^{\circ} \mathrm{C}$ reduced the bonding shear strengths of $\mathrm{AZO} / \mathrm{Cu}$ and $\mathrm{ZnO} / \mathrm{Cu}$ joints to 3.3 and $3.7 \mathrm{MPa}$, respectively.
\end{abstract}

\section{Introduction}

Transparent conductive oxide (TCO) layers such as indiumtin-oxide (ITO), aluminum-doped zinc oxide (AZO), and zinc oxide $(\mathrm{ZnO})$ are widely applied in optoelectronic devices such as huge touch panels, flat-panel displays, photovoltaics, electrically heatable glass, opto-electrical interfaces, and circuitry [1]. Due to their lower cost than that of ITO film, wide band gap, and large exciton binding energy, AZO and $\mathrm{ZnO}$ films have attracted much attention. Among the multiple methods of depositing TCO thin film layers onto desired substrates, such as evaporation, spray pyrolysis, chemical vapor deposition, sol-gel, and sputtering, magnetron sputtering is the most attractive technique because of its good reproducibility, high deposition rate, and best deposition results in terms of the conductivity and transparency of thin film layers [2,3]. The backing plate provides electrical conductivity and heat transfer, and it also supports the target material during sputtering to keep the target from falling off and to avoid cracking of the brittle ceramic target. Thus, the ceramic sputter target must be bonded to copper backing plates of high conductivity. The integrity of the bond between the sputtering target and the backing plate is critical to the performance of the sputtering.

Metallic bonds inherently exhibit high thermal and electrical conductivity and are also used as a thermal interface material for reducing the thermal resistance between the TCO sputtering target and copper backing plate. As a result, solder bonded targets are able to operate at higher power densities and deposition rates can be enhanced without overheating or cracking of the targets. However, ceramics are usually ionic, covalent, or ionic-covalent bonded materials. The high energy of ion and covalent bonds makes ceramics chemically inert. Thus, most fillers used for 
ceramic bonding cannot be wetted on their surfaces below $800^{\circ} \mathrm{C}[4,5]$. Such a high bonding temperature may cause high residual stress, cracking, or functional degradation of the transparent conductive oxides.

Active solders containing active alloying elements, such as titanium, rare earth elements, aluminum, and magnesium, have been developed to join ceramics at low temperatures without a protective atmosphere [6]. The active alloying elements play a key role in affecting the wettability and the interfacial reactivity between solder and ceramic [7, 8]. For example, Fu et al. [9] demonstrated that the addition of about $4-10 \mathrm{wt} . \%$ titanium to $\mathrm{Sn}-\mathrm{Ag}-\mathrm{Cu}$ alloy resulted in a significant enhancement of the wettability and the soldering ability of the lead-free solder alloy. The same phenomenon is similar to the In-Ag-Ti active solder [10]. Moreover, both $\mathrm{Al}$ and $\mathrm{Mg}$ are very chemically active elements, with low cost and lower melting point. Wu et al. [11] have successfully performed the ultrasonic-assisted air soldering of $\mathrm{SiC} / \mathrm{SiC}$ ceramic by using $\mathrm{Sn}-\mathrm{Zn}-\mathrm{Al}$ active solder. Koleňák et al. $[12,13]$ studied the direct bonding of $\mathrm{Al}_{2} \mathrm{O}_{3} /$ $\mathrm{Cu}$ and silicon using $\mathrm{Sn}_{2} \mathrm{La}$ and $\mathrm{Sn}-\mathrm{Ag}-\mathrm{Ti}(\mathrm{Mg})$ solders, respectively. Their results demonstrated that adding active elements into the active solder can effectively enhance the soldering ability and that satisfactory joining with ceramics can be achieved. Prior study [14] and the studies by Zhao et al. [15] and Gorjan et al. [16] have demonstrated that adding an active element such as $\mathrm{Ti}$ and trace rare earth elements to lead-free $\mathrm{Sn}-\mathrm{Ag}, \mathrm{Sn}-\mathrm{Ag}-\mathrm{Cu}, \mathrm{Sn}-\mathrm{Zn}$, and $\mathrm{Sn}-\mathrm{Bi}$ fillers significantly enhances their wettability, and such fillers have been used to join ceramic and metal at low temperature. The active soldering process, which is usually carried out in air, requires mechanical activation such as edge abrasion, brushing, and ultrasonic vibration to destroy the oxide layer that forms on the molten filler metal and thereby to permit the interfacial interaction of the active elements, rare earth elements, titanium, or magnesium with the ceramics [14].

Among the many $\mathrm{Pb}$-free solders developed to date, $\mathrm{Sn}$ $\mathrm{Zn}$ alloys are regarded as promising candidates due to their merits of good mechanical performance and low cost. The addition of 3 wt.\% Bi into eutectic Sn-9Zn solder alloy reduces the liquidus temperature to one close to that of eutectic $\mathrm{Sn}-\mathrm{Pb}$ alloy and can improve the wettability, mechanical properties, and corrosion resistance [17]. Moreover, $\mathrm{ZnO}$-based TCO is a promising alternative to the commonly utilized ITO, which is nontoxic, low cost, and highly durable against hydrogen plasma [18]. In the present work, a novel $\mathrm{Sn}_{8} \mathrm{Zn}_{3} \mathrm{Bi}_{1} \mathrm{Mg}$ active solder was developed and used to join $\mathrm{AZO}$ and $\mathrm{ZnO}$ targets with oxygen-free copper backing plates. The fluxless direct active soldering process was carried out in air without flux, thus further reducing the cost of the bonding. During the sputtering process, large ion currents were generated and caused very intense and localized heating of the target. Generally, a higher power input causes the temperature of the target to increase sharply [19], which in turn limits sputtering rates and final film properties. Therefore, the effect of temperature on the joint strengths was evaluated by shear testing at 120,150 , and $180^{\circ} \mathrm{C}$ in this study.

\section{Experimental}

The materials joined in this study were oxygen-free copper and aluminum-doped zinc oxide (AZO) composed of a mixture of 98 wt. $\% \mathrm{ZnO}$ and 2 wt.\% $\mathrm{Al}_{2} \mathrm{O}_{3}$ and ceramic targets of zinc oxide $(\mathrm{ZnO})$. The active solder $\mathrm{Sn}_{8} \mathrm{Zn}_{3} \mathrm{Bi}_{1} \mathrm{Mg}$ was prepared from $\mathrm{Sn}, \mathrm{Zn}$, and $\mathrm{Bi}$ of $99.99 \%$ purity in the shape of slugs and flaky AZ31 magnesium alloy in a vacuum arc furnace under a high-purity argon atmosphere. The chemical composition of AZ31 magnesium alloy is provided in Table 1. To ensure a homogenous composition within the alloy, the $\mathrm{Sn}_{8} \mathrm{Zn}_{3} \mathrm{Bi}_{1} \mathrm{Mg}$ active solder was remelted at least 3 times. After the solder alloy was solidified in a water-cooled copper mold, the cast ingot was rolled to a thickness of $50 \mu \mathrm{m}$. The chemical composition of the active solder used in this study was determined by an X-ray fluorescence spectrometer (XRF, Olympus Innov-X Delta) and is given in Table 2.

Differential scanning calorimetry (DSC 204 F1 Phoenix, Netzsch) was used to determine the melting range (liquidus and solidus) of the active solder at a heating rate of $10^{\circ} \mathrm{C} / \mathrm{min}$ from room temperature to $250^{\circ} \mathrm{C}$ in an $\mathrm{Ar}$ atmosphere. An electron probe microanalyzer (EPMA, JEOL TXA-8600SX) equipped with wavelength-dispersive X-ray spectrometer (WDS) was used to analyze the chemical composition and chemical distributions of the elements of the solder alloy. The microstructure of the solder alloy was observed with a scanning electron microscope (FE-SEM, Philips XL40).

The TCO specimens supplied for soldering were processed to a size of $7 \mathrm{~mm} \times 7 \mathrm{~mm} \times 5 \mathrm{~mm}$, as shown in Figure 1(a). Prior to soldering, all bonding surfaces of AZO, $\mathrm{ZnO}$, and copper and the surfaces of the solder alloy were wet-ground with $\mathrm{SiC}$ paper down to grade 1200. In active soldering, the $\mathrm{AZO}$ and $\mathrm{ZnO}$ specimens were pre-heated to $200^{\circ} \mathrm{C}$ on a heating plate for about 5 minutes in air. Subsequently, the $50 \mu \mathrm{m}$ thick foil of the active solder was then placed on the AZO and $\mathrm{ZnO}$ surfaces. The molten solder alloy was agitated for about 30 seconds for wetting on the surfaces, and then the joints were tightly held with about $1 \mathrm{~kg}$ force on the aluminum plate and naturally cooled in air, leading to the solidification of the $\mathrm{Sn}_{8} \mathrm{Zn}_{3} \mathrm{Bi}_{1} \mathrm{Mg}$ active solder. For the metallographic observations of the joint interfaces, the soldered specimens were cross-sectioned and characterized with a scanning electron microscope and energy dispersive X-ray (EDS). The joining strengths were measured at room temperature, 120,150 , and $180^{\circ} \mathrm{C}$ by shear testing, which was performed on a tensile testing machine (Hung Ta HT-2102BI). At least 4 shear tests were performed, and the highest bonding strengths values were obtained from the valid test results. The dimensions and geometry of the joints subjected to shear testing are shown in Figures 1(a) and $1(\mathrm{~b})$.

\section{Results and Discussion}

The microstructure of the cast $\mathrm{Sn}_{8} \mathrm{Zn}_{3} \mathrm{Bi}_{1} \mathrm{Mg}$ active solder consisted of stripe-like $\mathrm{Sn}-\mathrm{Zn}$ eutectic phase, needle-like $\mathrm{Zn}$ rich phase (black), Bi-rich phase particles (bright), and granular $\mathrm{Mg}$-Sn intermetallic compound particles, as shown 
TABLE 1: The chemical composition of AZ31 magnesium alloy (wt.\%).

\begin{tabular}{cccccccc}
\hline $\mathrm{Al}$ & $\mathrm{Zn}$ & $\mathrm{Mn}$ & $\mathrm{Si}$ & $\mathrm{Fe}$ & $\mathrm{Cu}$ & $\mathrm{Ni}$ & $\mathrm{Mg}$ \\
\hline 3.0 & 1.0 & 0.2 & 0.02 & $\leqq 0.01$ & $\leqq 0.01$ & $\leqq 0.01$ & $\mathrm{Bal}$ \\
\hline
\end{tabular}

TABLE 2: The chemical composition of the $\mathrm{Sn}_{8} \mathrm{Zn}_{3} \mathrm{Bi}_{1} \mathrm{Mg}$ active solder (wt.\%).

\begin{tabular}{lccccc}
\hline $\mathrm{Zn}$ & $\mathrm{Bi}$ & $\mathrm{Mg}$ & $\mathrm{Al}$ & \\
\hline 8.01 & 3.01 & 0.96 & 0.03 & Sn \\
\hline
\end{tabular}

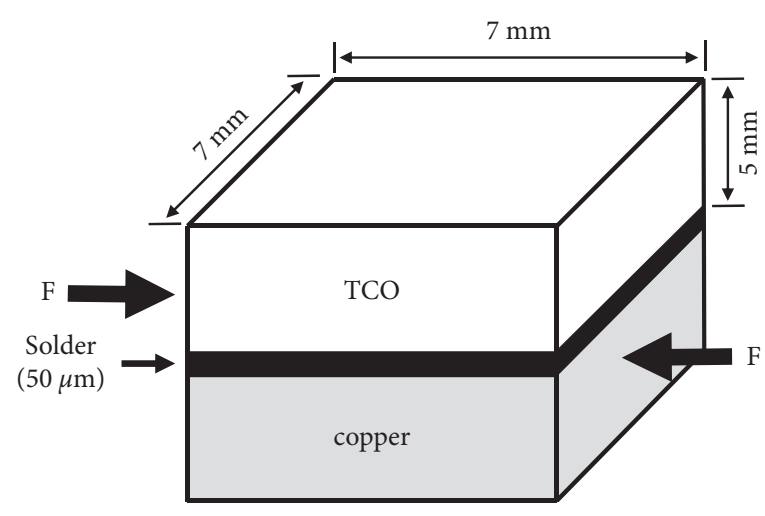

(a)

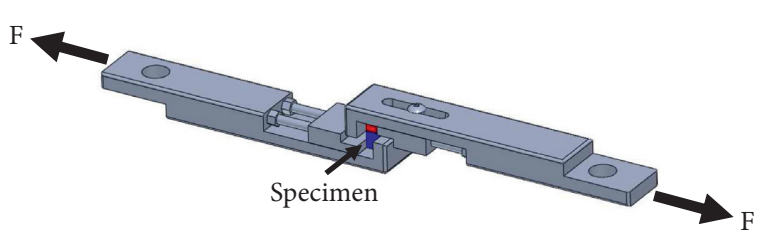

(b)

Figure 1: The geometry and dimensions of the joints subjected to shear testing. (a) Schematic representation of the soldered specimen. (b) Schematic representation of the grips for tensile shear testing.

in Figure 2. The EPMA analyses indicated that the chemical composition of the $\mathrm{Mg}-\mathrm{Sn}$ intermetallic compound was $\mathrm{Mg}$ : $\mathrm{Sn}=65.6: 34.4$ (at.\%). According to $\mathrm{Sn}-\mathrm{Mg}-\mathrm{Zn}$ ternary phase diagram [20] and the compositional analysis, the intermetallic compound corresponds to the $\mathrm{Mg}_{2} \mathrm{Sn}$ phase.

Figure 3 presents the differential scanning calorimetry (DSC) curves of $\mathrm{Sn}_{8} \mathrm{Zn}_{3} \mathrm{Bi}_{1} \mathrm{Mg}$ active solder, indicating the endothermic reactions associated with melting. An endothermic process up to approximately $181.1^{\circ} \mathrm{C}$ was found in the DSC curve of the alloy and attributed to the existence of a nearly eutectic composition of $\mathrm{Sn}-\mathrm{Zn}-\mathrm{Mg}$ alloy [20]. The $\mathrm{Sn}_{8} \mathrm{Zn}_{3} \mathrm{Bi}_{1} \mathrm{Mg}$ active solder showed a large endothermic peak at higher temperature, approximately $198.6^{\circ} \mathrm{C}$, corresponding to the eutectic temperature of the $\mathrm{Zn}$-Sn binary alloy.

Cross-sectional SEM micrographs of the bonding interfaces of $\mathrm{AZO} / \mathrm{Cu}$ and $\mathrm{ZnO} / \mathrm{Cu}$ joints joined with the $\mathrm{Sn}_{8} \mathrm{Zn}_{3} \mathrm{Bi}_{1} \mathrm{Mg}$ active solder at $200^{\circ} \mathrm{C}$ are shown in Figures 4 and 5 , respectively. Those figures demonstrate the good wettability of the active filler metal and satisfactory bonding interfaces both between $\mathrm{AZO}$ and copper and between $\mathrm{ZnO}$ and copper. The copper dissolved irregularly to form a thin intermetallic compound layer with a thickness of about $0.5 \mu \mathrm{m}$ at the solder/copper interface. The EDS analysis indicated that the composition of the intermetallic layer was $\mathrm{Cu}: \mathrm{Sn}=41.1: 58.9 \quad$ (at.\%), which corresponds to the $\gamma-\mathrm{Cu}_{5} \mathrm{Zn}_{8}$ IMCs. At the $\mathrm{AZO} /$ solder and $\mathrm{ZnO} /$ solder interfaces, no reaction products were observed after the bonding.

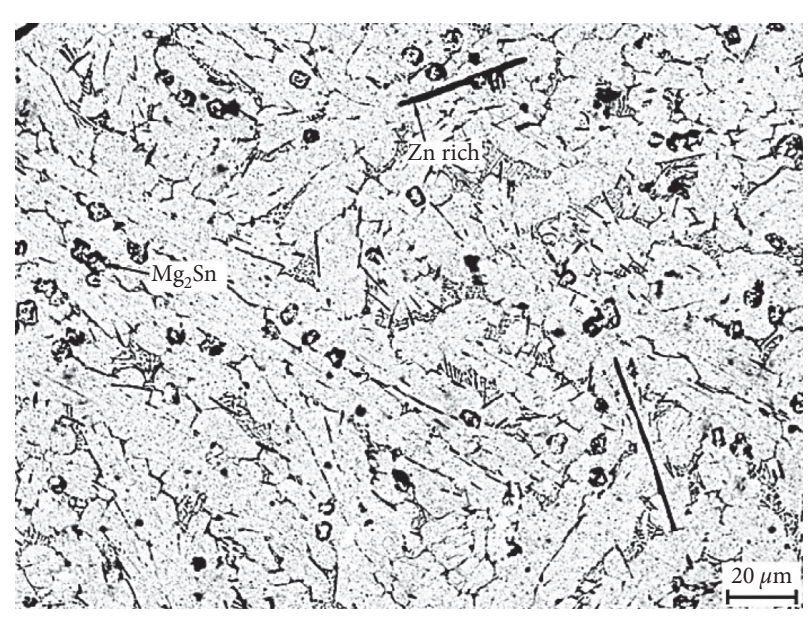

Figure 2: Microstructure of the $\mathrm{Sn}_{8} \mathrm{Zn}_{3} \mathrm{Bi}_{1} \mathrm{Mg}$ active solder.

The AZO and $\mathrm{ZnO}$ are too brittle and easily break during shear test. After 4 shear tests in each condition, the highest bonding shear strengths values were obtained from the valid test results. The shear strengths of $\mathrm{AZO} / \mathrm{Cu}$ and $\mathrm{ZnO} / \mathrm{Cu}$ joints bonded with the $\mathrm{Sn}_{8} \mathrm{Zn}_{3} \mathrm{Bi}_{1} \mathrm{Mg}$ active solder were 10.3 and $7.5 \mathrm{MPa}$, respectively. Figure 6 shows the joining strengths of $\mathrm{AZO} / \mathrm{Cu}$ and $\mathrm{ZnO} / \mathrm{Cu}$ joints measured at room temperature, 120,150 , and $180^{\circ} \mathrm{C}$. These results indicated that the joint strengths decreased with increases in testing temperature. The lower shear strengths of the $\mathrm{AZO} / \mathrm{Cu}$ and $\mathrm{ZnO} / \mathrm{Cu}$ joints at high temperatures could be attributed to the lower strength of 


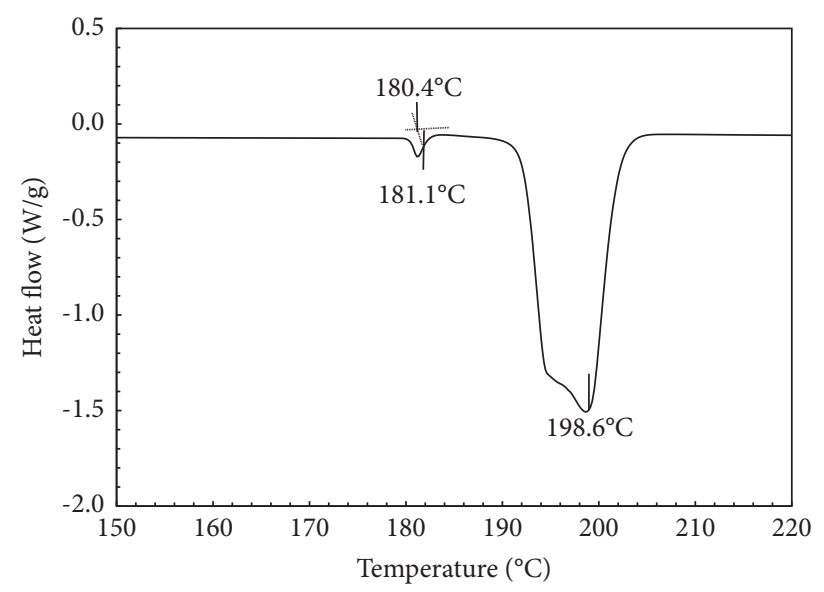

FIgure 3: DSC analysis of the $\mathrm{Sn}_{8} \mathrm{Zn}_{3} \mathrm{Bi}_{1} \mathrm{Mg}$ active solder.

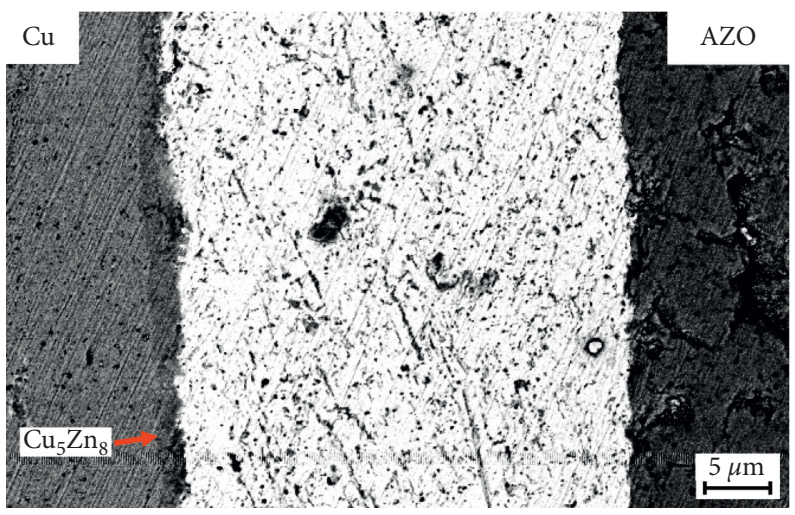

FIgURE 4: Cross-sectional SEM micrograph of $\mathrm{AZO} / \mathrm{Cu}$ joint bonded with $\mathrm{Sn}_{8} \mathrm{Zn}_{3} \mathrm{Bi}_{1} \mathrm{Mg}$ active solder.

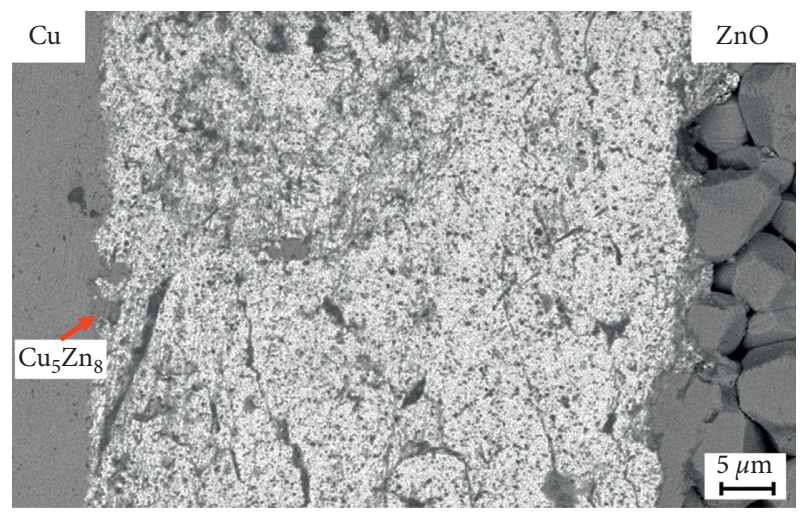

Figure 5: Cross-sectional SEM micrograph of $\mathrm{ZnO} / \mathrm{Cu}$ joint bonded with $\mathrm{Sn}_{8} \mathrm{Zn}_{3} \mathrm{Bi}_{1} \mathrm{Mg}$ active solder.

the solder alloy at temperatures above $120^{\circ} \mathrm{C}$. The joint strength remained at about $4 \mathrm{MPa}$ at $180^{\circ} \mathrm{C}$, very near the liquefaction temperature of the alloy $\left(180.4^{\circ} \mathrm{C}\right)$. Figures 7 and 8 present the fractography of $\mathrm{AZO} / \mathrm{Cu}$ joints with $\mathrm{Sn}_{8} \mathrm{Zn}_{3} \mathrm{Bi}_{1} \mathrm{Mg}$ active solder after shear tests at room temperature and at $180^{\circ} \mathrm{C}$. The fractography of $\mathrm{ZnO} / \mathrm{Cu}$ joints with $\mathrm{Sn}_{8} \mathrm{Zn}_{3} \mathrm{Bi}_{1} \mathrm{Mg}$ active solder after shear tests at room temperature and at $180^{\circ} \mathrm{C}$ is shown in

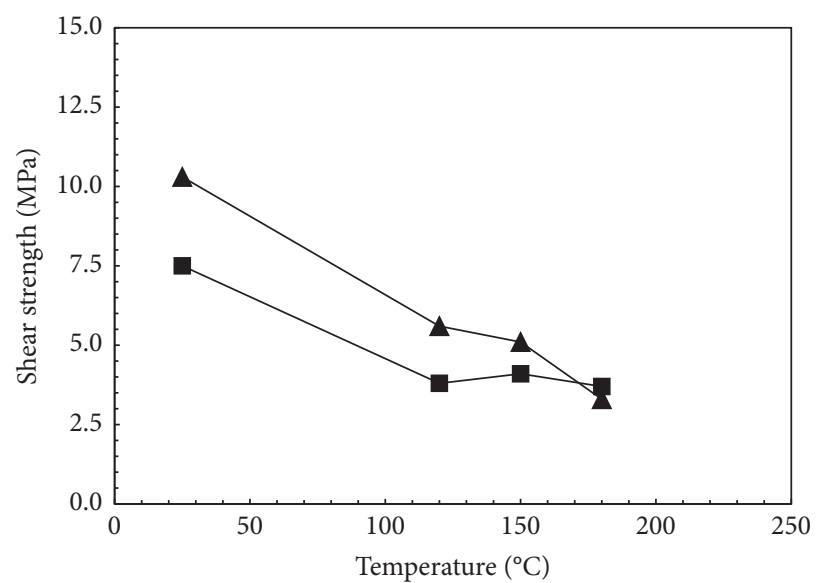

\section{$\Delta \mathrm{AZO} / \mathrm{Cu}$ \\ $\mathrm{ZnO} / \mathrm{Cu}$}

FIgURE 6: The shear strengths of $\mathrm{AZO} /$ copper and $\mathrm{ZnO} /$ copper joints bonded with $\mathrm{Sn}_{8} \mathrm{Zn}_{3} \mathrm{Bi}_{1} \mathrm{Mg}$ solder at various temperatures.

Figures 9 and 10, respectively. All fractured surfaces of the copper were covered with a $\mathrm{Sn}_{8} \mathrm{Zn}_{3} \mathrm{Bi}_{1} \mathrm{Mg}$ active solder layer, which indicated that both joints fractured along the $\mathrm{AZO} /$ 


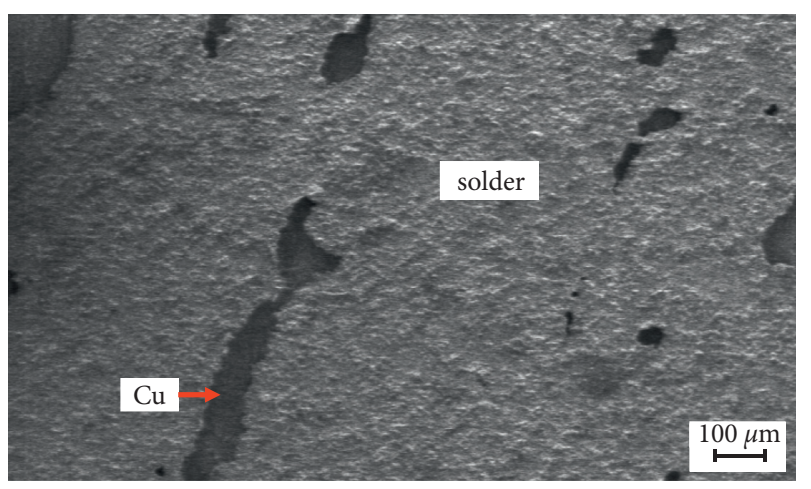

(a)

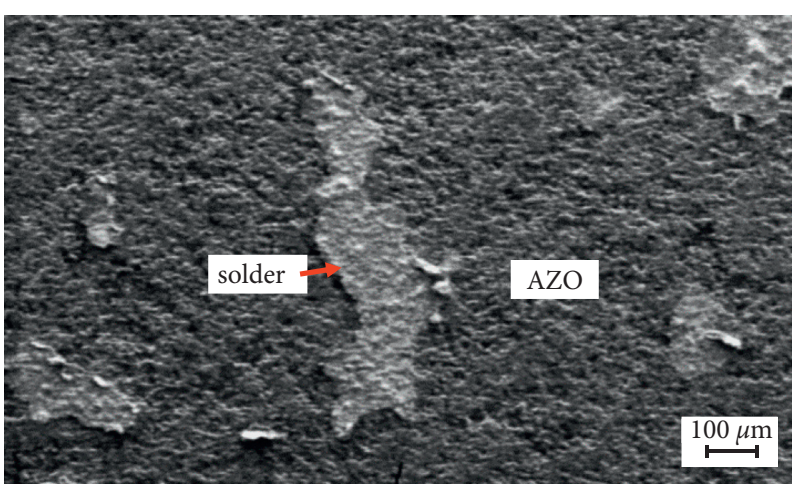

(b)

FIGURE 7: Fractography of an AZO/Cu joint with $\mathrm{Sn}_{8} \mathrm{Zn}_{3} \mathrm{Bi}_{1} \mathrm{Mg}$ active solder after shear tests at room temperature: (a) the Cu side; (b) the AZO side.

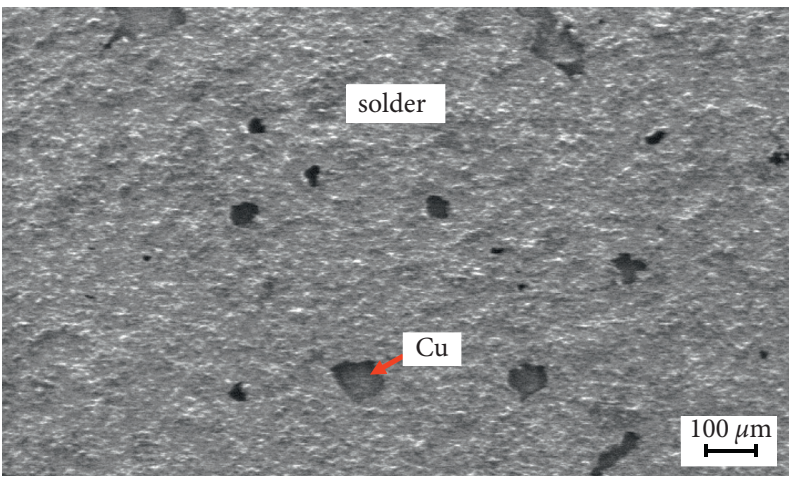

(a)

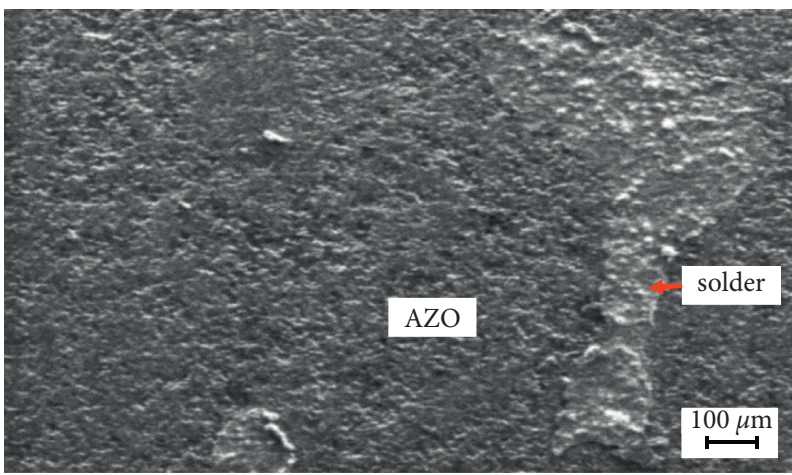

(b)

Figure 8: Fractography of an $\mathrm{AZO} / \mathrm{Cu}$ joint with $\mathrm{Sn}_{8} \mathrm{Zn}_{3} \mathrm{Bi}_{1} \mathrm{Mg}$ active solder after shear tests at $180^{\circ} \mathrm{C}$ : (a) the $\mathrm{Cu}$ side; (b) the $\mathrm{AZO}$ side.

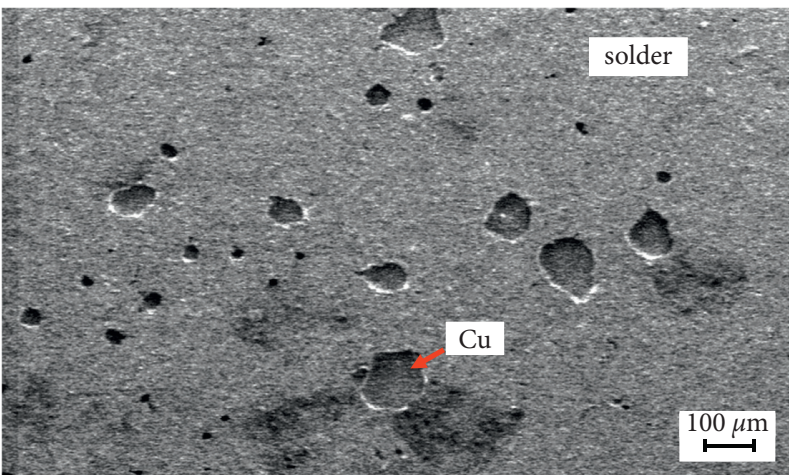

(a)

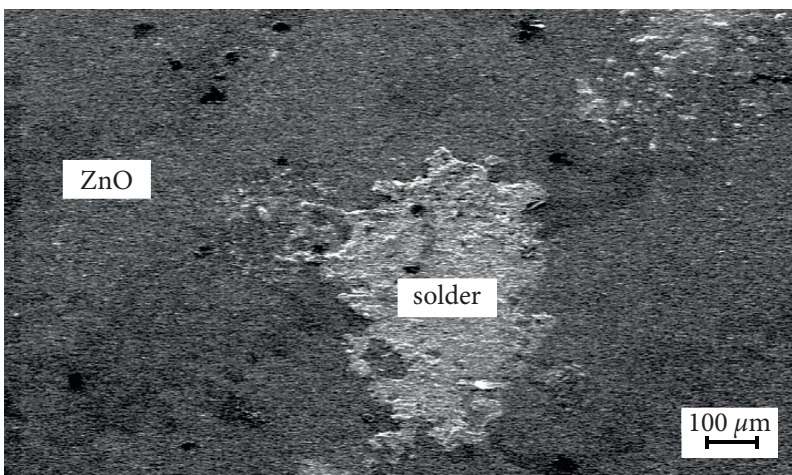

(b)

FiguRE 9: Fractography of a $\mathrm{ZnO} / \mathrm{Cu}$ joint with $\mathrm{Sn}_{8} \mathrm{Zn}_{3} \mathrm{Bi}_{1} \mathrm{Mg}$ active solder after shear tests at room temperature: (a) the $\mathrm{Cu}$ side; (b) the $\mathrm{ZnO}$ side. 


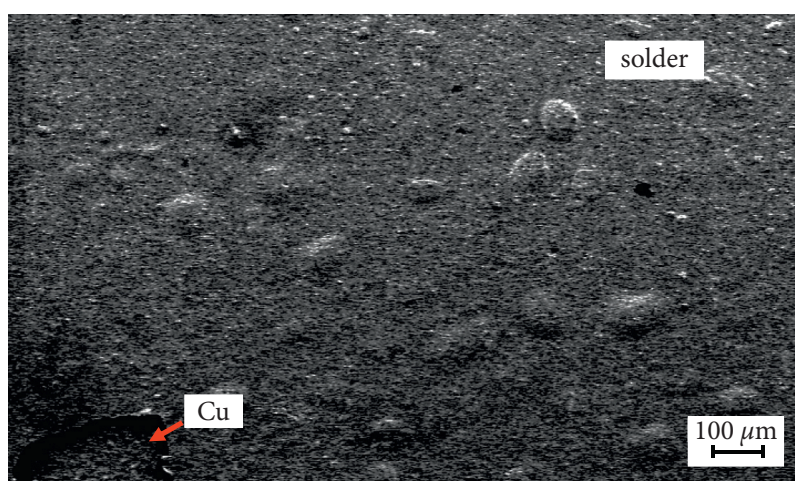

(a)

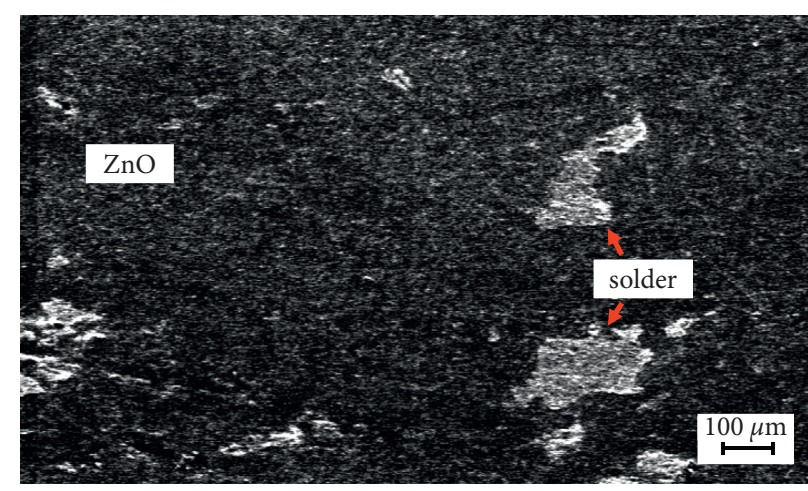

(b)

Figure 10: Fractography of a $\mathrm{ZnO} / \mathrm{Cu}$ joint with $\mathrm{Sn}_{8} \mathrm{Zn}_{3} \mathrm{Bi}_{1} \mathrm{Mg}$ active solder after shear tests at $180^{\circ} \mathrm{C}$ : (a) the $\mathrm{Cu}$ side; (b) the $\mathrm{ZnO}$ side.

solder and $\mathrm{ZnO} /$ solder interfaces. Few of active solder was on the fractured surfaces of the AZO or $\mathrm{ZnO}$ side after the shear test at $180^{\circ} \mathrm{C}$.

\section{Conclusion}

In this study, $\mathrm{AZO} / \mathrm{Cu}$ and $\mathrm{ZnO} / \mathrm{Cu}$ were joined at $200^{\circ} \mathrm{C}$ in air by using a novel $\mathrm{Sn}_{8} \mathrm{Zn}_{3} \mathrm{Bi}_{1} \mathrm{Mg}$ active solder. The liquidus temperature of the $\mathrm{Sn}_{8} \mathrm{Zn}_{3} \mathrm{Bi}_{1} \mathrm{Mg}$ active solder was very close to the binary $\mathrm{Sn}-\mathrm{Zn}$ eutectic temperature $\left(198.5^{\circ} \mathrm{C}\right)$. Satisfactory joints of $\mathrm{AZO} / \mathrm{Cu}$ and $\mathrm{ZnO} / \mathrm{Cu}$ were realized at $200^{\circ} \mathrm{C}$ in air without pre-metallization for $\mathrm{AZO}$ and $\mathrm{ZnO}$. It was found that during the soldering process, copper dissolved and diffused into the solder, forming $\mathrm{Cu}_{5} \mathrm{Zn}_{8}$ intermetallic compounds. The shear strengths of the $\mathrm{AZO} / \mathrm{Cu}$ and $\mathrm{ZnO} / \mathrm{Cu}$ joints with $\mathrm{Sn}_{8} \mathrm{Zn}_{3} \mathrm{Bi}_{1} \mathrm{Mg}$ active solder at room temperature were $10.3 \mathrm{MPa}$ and $7.5 \mathrm{MPa}$, respectively. The joint strength decreased to $3.3 \mathrm{MPa}$ of $\mathrm{AZO} /$ $\mathrm{Cu}$ and $3.7 \mathrm{MPa}$ of $\mathrm{ZnO} / \mathrm{Cu}$, respectively, as the testing temperature increased to $180^{\circ} \mathrm{C}$. This active soldering process provides a low-cost, high-quality, and easy direct ceramic soldering technology with environmental benefits.

\section{Data Availability}

The data used to support the findings of this study are available from the corresponding author upon request.

\section{Conflicts of Interest}

The authors declare that they have no conflicts of interest.

\section{Acknowledgments}

The authors acknowledge the financial support from the Ministry of Science and Technology of Taiwan, R.O.C., under project no. MOST 108-2221-E-224-031.

\section{References}

[1] R. A. Afre, N. Sharma, M. Sharon, and M. Sharon, "Transparent conducting oxide films for various applications: a review," Reviews on Advanced Materials Science, vol. 53, no. 1, pp. 79-89, 2018.
[2] F.-H. Wang, J.-C. Chao, H.-W. Liu, and T.-K. Kang, "Physical properties of $\mathrm{ZnO}$ thin films codoped with titanium and hydrogen prepared by RF magnetron sputtering with different substrate temperatures," Journal of Nanomaterials, vol. 2015, pp. 1-11, 2015.

[3] K. H. Patel and S. K. Rawal, "Influence of power and temperature on properties of sputtered AZO films," Thin Solid Films, vol. 620, pp. 182-187, 2016.

[4] Y. H. Chai, W. P. Weng, and T. H. Chuang, "Relationship between wettability and interfacial reaction for Sn10Ag4Ti on $\mathrm{Al} 2 \mathrm{O} 3$ and $\mathrm{SiC}$ substrates," Ceramics International, vol. 24, no. 4, pp. 273-279, 1998.

[5] R. M. do Nascimento, A. E. Martinelli, and A. J. A. Buschinelli, "Review article: recent advances in metal-ceramic brazing," Cerâmics, vol. 49, pp. 178-198, 2003.

[6] F. Hillen, D. Pickart-Castillo, I. J. Rass, and E. Lugscheider, "Solder alloys and soldering processes for flux-free soldering of difficult-to-wet materials," Welding and Cutting, vol. 52, no. 8, pp. E162-E165, 2000.

[7] L. Gremillard, E. Saiz, V. R. Radmilovic, and A. P. Tomsia, "Role of titanium on the reactive spreading of the lead-free solders on alumina," Journal of Materials Research, vol. 21, pp. 3222-3233, 2006.

[8] L. X. Cheng, M. R. Liu, X. Q. Wang, B. H. Yan, and G. Y. Li, "Effect of active element Ti on interfacial microstructure and bonding strength of $\mathrm{SiO}_{2} / \mathrm{SiO}_{2}$ joins soldered using $\mathrm{Sn}_{3.5} \mathrm{Ag}_{4} \mathrm{Ti}$ (Ce, Ga) alloy filler," Materials Science and Engineering A, vol. 680, pp. 317-323, 2017.

[9] W. Fu, X. G. Song, Y. X. Zhao et al., "Effect of Ti content on the wetting behavior of $\mathrm{Sn}_{0.3} \mathrm{Ag}_{0.7} \mathrm{Cu} / \mathrm{AlN}$ system," Materials \& Design, vol. 115, pp. 1-7, 2017.

[10] R. Koleňák, I. Kostolný, J. Drápala, M. Sahul, and J. Urminský, "Characterizing the soldering alloy type In-Ag-Ti and the study of direct soldering of SiC ceramics and copper," Metals, vol. 8, no. 4, p. 274, 2018.

[11] B. Wu, W. Guo, J. He, Z. Xiu, and J. Yan, "Microstructure evolution of $\mathrm{SiC} / \mathrm{SiC}$ joints during ultrasonic-assisted air bonding using a Sn-Zn-Al alloy," Ceramics International, vol. 44, no. 2, pp. 1284-1290, 2018.

[12] R. Koleňák and I. Kostolný, "Study of direct bonding ceramics with metal using $\mathrm{Sn}_{2} \mathrm{La}$ solder," Advances in Materials Science and Engineering, vol. 2015, pp. 1-13, Article ID 269167, 2015.

[13] R. Koleňák, I. Kostolný, and M. Sahul, "Direct bonding of silicon with solders type Sn-Ag-Ti," Soldering \& Surface Mount Technology, vol. 28, no. 3, pp. 149-158, 2016. 
[14] S. Y. Chang, L. C. Tsao, M. J. Chiang, C. N. Tung, G. H. Pan, and T. H. Chuang, "Active soldering of indium tin oxide (ITO) with $\mathrm{Cu}$ in air using an $\mathrm{Sn3.5Ag4Ti(Ce,} \mathrm{Ga)} \mathrm{filler,"}$ Journal of Materials Engineering and Performance, vol. 12, no. 4, pp. 383-389, 2003.

[15] G. J. Zhao, Y. X. Jing, G. M. Sheng, and J. H. Chen, "Effects of rapid solidification process and 0.1 wt.\% $\mathrm{Pr}$ addition on properties of $\mathrm{Sn}-9 \mathrm{Zn}$ alloy and $\mathrm{Cu} /$ solder/Cu joints," Journal of Materials Engineering and Performance, vol. 25, pp. 2037-2042, 2016.

[16] L. Gorjan, G. Blugan, M. Boretius et al., "Fracture behavior of soldered $\mathrm{Al} 2 \mathrm{O} 3$ ceramic to A356 aluminum alloy and resistance of the joint to low temperature exposure," Materials \& Design, vol. 88, pp. 889-896, 2015.

[17] G. Ren and M. N. Collins, "The effects of antimony additions on microstructures, thermal and mechanical properties of Sn8Zn-3Bi alloys," Materials \& Design, vol. 119, pp. 133-140, 2017.

[18] T. Minami, "Substitution of transparent conducting oxide thin films for indium tin oxide transparent electrode applications," Thin Solid Films, vol. 516, no. 7, pp. 1314-1321, 2008.

[19] Y. K. Moon, S. H. Kim, and J. W. Park, "The influence of substrate temperature on the properties of aluminum-doped zinc oxide thin films deposited by DC magnetron sputtering," Journal of Materials Science: Materials in Electronics, vol. 19, pp. 979-977, 2006.

[20] N. Ogawa, T. Miki, T. Nagasaka, and M. Hino, "Activity measurement of the constituents in molten Sn-Mg-Zn ternary lead free solder alloys by mass spectrometry," Materials Transactions, vol. 43, no. 12, pp. 3227-3233, 2002. 